\title{
OS LAUDOS PERICIAIS NAS AÇÕES JUDICIAIS POR ALEGADO ERRO MÉDICO: UMA ANÁLISE CRÍTICA
}

EXPERT REPORTS IN ALLEGED MEDICAL MALPRACTICE LAWSUITS: A CRITICAL ANALYSIS

\author{
Roberto Augusto de Carvalho Campos \\ Luiz Rogério Monteiro de Oliveira*
}

\begin{abstract}
Resumo:
A proposta deste trabalho é fazer uma apreciação crítica dos laudos periciais realizados em ações judiciais de responsabilidade civil por alegado erro médico. A prova pericial deve orientar o julgador para que este possa fixar os limites da responsabilidade do médico ou profissional de saúde. O perito deve responder adequadamente as questões discutidas no processo, bem como trazer ao juiz os elementos que considerar úteis ou necessários para auxiliar a decisão judicial. $\mathrm{Na}$ parte teórica são estudados os campos de apuração da responsabilidade por erro médico, os pressupostos da responsabilidade civil, os tipos de prova que podem ser produzidos no processo, quais são os elementos essenciais do laudo pericial e os critérios que devem ser usados pelo perito para determinar se estão presentes os requisitos do dever de indenizar. Em seguida, utilizando-se dados obtidos em processos judiciais, são abordados os aspectos mais relevantes nas ações desta espécie, como a incidência dos tipos de dano alegados pelos autores, as especialidades médicas mais acionadas judicialmente, o tempo médio entre o ajuizamento da ação e a sentença judicial e a relevância dos laudos nas decisões judiciais observadas. Ao final, é realizada uma análise crítica dos conteúdos dos laudos, verificando se eles contêm todos os elementos recomendados e descritos na parte teórica, fazendose críticas sobre se eles cumpriram sua função de forma adequada e propondo instrumentos para seu aperfeiçoamento.
\end{abstract}

Palavras-chave: Laudo pericial. Perito. Prova. Responsabilidade civil. Medicina Forense.

\begin{abstract}
:
The aim of this work is to do a critical appreciation of the expert reports in judicial proceedings for alleged medical malpractice. The expert report should guide the judge and help to determine the limits of the physician's or health professional's responsibility. The expert must answer appropriately the questions discussed in the lawsuit, as well as bringing the elements that he or she might consider useful or necessary to aid the judicial decision. The theoretical section concerns the medical malpractice responsibility verification, the presupposed civil responsibility, the kinds of proof that can be produced in the process, what are the essential elements of the expert report, and which criteria that should be used by the expert to determine if the requirements of the duty of compensating are present. Then, using data obtained from judicial proceedings, the most important aspects in this kind of lawsuit are exposed, such as the incidence of types of damage alleged by the authors, the most
\end{abstract}

Professor Doutor do Departamento de Direito Penal, Medicina Forense e Criminologia da Faculdade de Direito da Universidade São Paulo.

• Mestre em Direito pela Universidade de São Paulo. Juiz de Direito do Tribunal de Justiça de São Paulo. 
prosecuted medical specialties, the average time between the beginning of the action and the judicial sentence, and the relevance of the expert reports in the observed judicial decisions. At the end, a critical analysis of the reports is accomplished, verifying if they contain all the recommended elements described in the theoretical part, criticizing the accomplishment of their function, and proposing instruments for their improvement.

Keywords: Expert report. Expert. Proof. Civil Responsibility. Forensic Medicine.

Introdução

O número de demandas judiciais e administrativas contra profissionais da medicina e estabelecimentos de saúde tem crescido significativamente nos últimos anos.

As melhores condições de saneamento básico, prevenção de doenças e o próprio avanço da ciência médica contribuíram para o aumento da população e da expectativa de vida. Conseqüentemente, o número de médicos e de pacientes também aumentou.

Entretanto, vem se observando uma despersonalização das relações entre médico e paciente. Antigamente, as cidades eram menores e os médicos eram vistos como "profissionais de família" Sua autoridade e posição social eram incontestáveis.

Na opinião de França (1994, p. 234), as relações entre os pacientes e os "médicos de família" foram substituídas por um relacionamento por vezes frio e impessoal, principalmente nas grandes cidades.

Citando Strauss, França registra que:

Em lugar do velho estilo de cabeceira, o médico de hoje em dia parece depender mais de um formidável aparato instrumental, que salva vidas perdidas por seus predecessores. A imagem do pai foi substituída pelo técnico especializado (STRAUSS, 1971, p. 4).

Pondera ainda este autor que a imagem de autoridade e conhecimento indiscutíveis do médico praticamente não existe mais. Atualmente ele é considerado um profissional que ganha a vida como outro qualquer, devendo em razão disso responder pelos erros que vier a cometer. Um paciente lesionado ou insatisfeito possui uma disposição muito maior de demandar contra um profissional distante e impessoal do que contra um amigo e conhecido da família.

Com o surgimento de novas especialidades e técnicas, o número de procedimentos médicos tem aumentado. No passado, os médicos se limitavam a diminuir 
o sofrimento do paciente e as intervenções cirúrgicas eram raras. Hoje as especialidades médicas chegam a dezenas (em 2006/2007 eram reconhecidas 53 especialidades médicas e 54 áreas de atuação pelo Conselho Federal de Medicina, Associação Médica Brasileira e Comissão Nacional de Residência Médica). ${ }^{1}$

O aumento dos casos de erro médico também está relacionado à sobrecarga de trabalho a que estão submetidos os profissionais da área. Pesquisa realizada pelo CREMESP em $2007^{2}$ revelou que os médicos paulistas cumprem carga horária excessiva e acumulam múltiplos empregos.

Na média, os médicos paulistas trabalham 52 horas por semana, sendo que $30 \%$ destes profissionais afirmam trabalhar mais de 60 horas semanais. O valor médio declarado para consulta particular é de $\mathrm{R} \$ 145,00$, enquanto o valor médio da consulta paga pelo plano de saúde é de $\mathrm{R} \$ 30,00$.

A insuficiência de profissionais em hospitais públicos e os baixos valores pagos pelos convênios particulares podem fazer com que os médicos reduzam o tempo das consultas, tornando-as por vezes superficiais. No caso das cirurgias, muitas delas são realizadas em seqüência e sem o necessário descanso, o que aumenta a possibilidade de erros.

Por sua vez, a estrutura do Poder Judiciário não acompanha o aumento do número de ações, em razão da escassez de recursos materiais e humanos. Em conseqüência disso, cada juiz tem um número maior de processos para examinar, implicando no sacrifício do tempo destinado a cada um.

Outro ponto de reflexão é que o desenvolvimento da tecnologia vem criando novos procedimentos, métodos, técnicas e conceitos, o que exige constante atualização dos profissionais de cada área e gera dificuldades para aqueles que precisam aprender $\mathrm{e}$ analisar termos técnicos e específicos.

$\mathrm{Na}$ prática jurisdicional, verifica-se que o número de profissionais habilitados e voltados para a perícia é inferior ao necessário. Em cidades pequenas, muitas vezes não há como se nomear como perito outro médico residente na mesma cidade, seja porque existe a chance de ser conhecido das partes do processo, seja porque nem sempre se encontram profissionais de todas as áreas de especialização.

Para tentar resolver estas dificuldades, é comum buscar peritos em outras cidades ou nomear profissionais pertencentes a órgãos públicos municipais ou estaduais. No Estado de São Paulo, em 1970 foi criado o Instituto de Medicina Social e de Criminologia de São Paulo (IMESC), tendo como suas principais atribuições a realização de perícias e

\footnotetext{
CONSELHO REGIONAL DE MEDICINA DO ESTADO DE SÃO PALLO. Especialidades médicas no Estado de São Paulo. São Paulo, 2008.

2 CONSElHO REGIONAL DE MEDICINA DO ESTADO DE SÃO PAUlO. O trabalho do médico no Estado de São Paulo. São Paulo, 2007.
} 
exames médicos requisitados pelas autoridades competentes (juízes de direito, delegados, promotores de justiça, procuradores do Estado e defensores públicos, entre outros).

Embora o IMESC possua em seus quadros profissionais de diversas áreas, o volume de trabalho é elevado, a ponto de afetar não apenas o tempo necessário para a realização do exame, como também para entrega dos laudos. Em 1995, o tempo médio de espera para a realização de um simples exame de paternidade por DNA era de 25 meses, estando atualmente em 12 meses. ${ }^{3}$ Após a realização do exame, as partes devem aguardar ainda a entrega do laudo, o que pode demorar mais alguns meses.

Existem poucas obras na doutrina brasileira a respeito da perícia que visa apurar se houve erro médico. A matéria envolve, além de todas as disciplinas médicas, ao menos cinco campos do Direito: Civil, Penal, Processual Civil, Processual Penal e Medicina Legal, os quais devem ser estudados em conjunto para se chegar a uma melhor compreensão das questões abordadas.

A prova pericial deve orientar o julgador para que este possa fixar os limites da responsabilidade do médico, respondendo adequadamente as questões discutidas no processo, bem como trazendo ao juiz os elementos que o perito considerar úteis ou necessários para auxiliar em suas decisões.

A proposta deste trabalho é de fazer uma apreciação crítica dos laudos periciais realizados em ações judiciais de responsabilidade civil por alegado erro médico.

A análise foi feita descrevendo-se as técnicas de elaboração dos laudos, fazendo-se críticas sobre se eles cumpriram sua função de forma adequada e, por fim, propondo instrumentos para seu aperfeiçoamento.

Concomitantemente, foram examinados outros pontos considerados relevantes nas ações judiciais desta espécie, os quais serão apresentados nas seções de metodologia, descrição dos resultados e discussão.

2. Revisão da literatura

2.1. O erro médico no mundo e no Brasil

Em alguns países o número de denúncias e demandas contra médicos ainda é baixo, como, por exemplo, na Suécia e em Portugal (KFOURY NETO, p. 56), onde a classe médica possui grande respeitabilidade.

Já em países como os Estados Unidos ocorre o oposto: trata-se se uma sociedade com um número elevado de advogados, voltada para a geração e resolução judicial de conflitos, o que ocasiona um grande número de pedidos de indenizações.

3 Home page do Governo do Estado de São Paulo. Disponível em: <http://www.justica.sp.gov.br/Modulo. asp?Modulo=111>. 
O professor França (1994, p. 235), em suas considerações, salienta que "nos Estados Unidos, realizou-se uma enquete e apurou-se que um bom número de demandantes questionava, não contra o médico, mas contra a companhia de seguros responsável" Os prêmios do seguro de responsabilidade civil profissional dos médicos e hospitais cresceram de forma insuportável, levando muitos médicos norte-americanos a se aposentarem precocemente ou abandonarem a profissão.

No Brasil, a divulgação de dispositivos da Constituição de 1988 pelos meios de comunicação, aliada à criação de leis especiais como o Código de Defesa do Consumidor, o Estatuto da Criança e do Adolescente e o Novo Código Civil, geraram um fortalecimento da cidadania e um maior esclarecimento da população. Isto provocou um sensível aumento no número de denúncias por erro médico, gerando demandas administrativas e judiciais.

Estudo realizado pelo CREMESP em $2007^{4}$ demonstrou que, nos últimos sete anos, o número de médicos denunciados naquele órgão aumentou $75 \%$ e o número de processos administrativos cresceu $120 \%$. Verificou-se que $35 \%$ das denúncias e $43 \%$ dos processos contra médicos estão relacionados à suposta má prática profissional (negligência, imprudência ou imperícia).

No mês de outubro de 2001 havia no Estado de São Paulo 2.800.910 ações cíveis em andamento (ações que ainda não foram julgadas ou na fase de execução). Já no mês de setembro de 2009 este número era de 4.922 .482 ações cíveis, ou seja, um aumento de $75,74 \%$ em apenas oito anos. ${ }^{5} \mathrm{O}$ número de ações judiciais por erro médico acompanhou este aumento do número de ações em geral.

Outro estudo realizado recentemente ${ }^{6}$ demonstrou que o número de processos judiciais por erro médico que chegaram ao Superior Tribunal de Justiça, última instância de recurso em matéria de legislação federal, passou de 23 no ano de 2001 para 360 em outubro de 2008 .

\subsection{Campos de apuração da responsabilidade por erro médico}

A responsabilização do médico por erros cometidos no exercício da profissão pode ser administrativa, civil ou penal. Trata-se de campos relativamente

\footnotetext{
CONSElHo REGIONAL DE MEDICINA DO ESTADO DE SÃo PAUlo. Denúncias e processos relacionados ao exercicio profissional da medicina no Estado de São Paulo no periodo de 2000 a 2006. São Paulo, 9 out. 2007.

5 Movimento Judiciário de Primeira Instância publicado pela Corregedoria Geral da Justiça do Estado de São Paulo, disponivel mensalmente no Diário da Justiça em: www.dje.tj.sp.gov.br.

6 SANT'ANNA, Emilio. Número de ações sobre erro médico no STJ cresce 17 vezes em 7 anos. O Estado de São Paulo, São Paulo, 13 nov. 2008. Disponível em: <http://www.estadao.com.br/estadaodehoje/20081113/ not_imp276831,0.php>. Acesso em: 20 nov. 2008.
} 
independentes, ou seja, a decisão formulada em um deles pode ou não influenciar no resultado dos demais. Os procedimentos em cada uma destas esferas são instaurados e tramitam independentemente.

A responsabilidade administrativa é apurada pelos órgãos de regulação da atividade profissional, quais sejam, o Conselho Regional de Medicina (CRM) de cada Estado e, como autoridade superior, o Conselho Federal de Medicina (CFM) localizado em Brasília, sendo a sanção mais grave a cassação do registro profissional, que impede o exercício da medicina. Já as responsabilidades civil e criminal são apuradas pelo Poder Judiciário. A primeira decorre da existência de um dano passível de ser reparado financeiramente, enquanto a segunda ocorre quando o médico pratica um ato expressamente previsto na legislação de natureza penal.

\subsection{Responsabilidade subjetiva e objetiva}

A responsabilidade subjetiva se fundamenta na teoria da culpa. O dever de indenizar neste caso pressupõe três requisitos: a demonstração da culpa do profissional, a existência do dano e o nexo causal entre dano e culpa. Esta é a teoria adotada como regra geral pelo Código Civil.?

Já a responsabilidade objetiva possui suporte na teoria do risco. Segundo esta teoria, todo aquele que exerce uma atividade econômica deve assumir a responsabilidade de reparar os danos decorrentes do exercício dessa atividade, independentemente da existência de culpa.

Enquanto a responsabilidade subjetiva ou com culpa é a regra, a responsabilidade objetiva ou sem culpa somente é admitida nos casos expressamente previstos em lei. ${ }^{8}$

A responsabilidade objetiva também é adotada no art. 14 da Lei n. 9.078/90 (Código de Defesa do Consumidor), que dispõe que os fornecedores de serviços (caso dos hospitais, clínicas e planos de saúde) respondem pela reparação dos danos causados aos consumidores por defeitos relativos à prestação dos serviços, independentemente da demonstração de culpa.

Existe, porém, uma ressalva no $\S 4^{\circ}$ do mesmo artigo, o qual prevê que a responsabilidade pessoal dos profissionais liberais só pode ser declarada mediante a

7 Art. 186 do CC: "Aquele que, por ação ou omissão voluntária, negligência ou imprudência. violar direitoe causar duno a outrem, ainda que exclusivamente moral, comete ato ilicito."

8 Art. 927 do CC: "Aquele que, por ato ilicito (arts. 186 e 187), causar dano a outrem. fica obrigado a repará-lo. Parágrafo único. Haverá obrigação de reparar o dano, independentemente de culpa, nos casos especificados em lei, ou quando a atividade normalmente desenvolvida pelo autor do dano implicar, por sua natureza, risco para os direitos de outrem." 
verificação de culpa. Aplica-se então a teoria da responsabilidade subjetiva quando o médico for profissional liberal, abrangendo-se no caso a pessoa física.

As responsabilidades do médico e do fornecedor de serviços são solidárias (art. 186 e 942 do Código Civil e art. $7^{\circ}$, parágrafo único, 25, § $1^{\circ}$ e 34 do CDC).

\subsection{Responsabilidade extracontratual e contratual}

A responsabilidade extracontratual, também chamada delitual, abrange os fatos ocorridos entre pessoas que não tem nenhuma relação jurídica antecedente, como, por exemplo, um acidente de trânsito entre um motorista e um pedestre. Observe-se que o termo delito aqui considerado não é apenas o da esfera criminal, abrangendo também o ilícito civil.

Já a responsabilidade contratual é aquela em que existe algum tipo de relação jurídica ou contrato previamente estabelecidos entre as partes envolvidas. $\mathrm{O}$ contrato pode assumir duas formas: escrito (em papel ou outro suporte material) ou verbal (quando houver uma combinação entre as partes, sem formalização por escrito).

Em regra, a responsabilidade do médico é contratual, mas pode haver casos de responsabilidade extracontratual, como, por exemplo, o médico fornecer atestado falso ou operar sem estar habilitado para tal.

\subsection{Obrigação de meio e de resultado}

$\mathrm{Na}$ obrigação de meio, o médico não se compromete a curar o paciente, e sim a usar todos os meios adequados e existentes na ciência médica para tratá-lo. Já na obrigação de resultado, o médico assume o compromisso de atingir um objetivo específico.

$\mathrm{Na}$ ação indenizatória do primeiro tipo (obrigação de meio), o autor deve provar o descumprimento do contrato (ou seja, a culpa), o dano sofrido e o nexo causal entre eles. A culpa do médico, pela natureza desse tipo de contrato, estará configurada quando os seus serviços tiverem sido prestados fora dos padrões técnicos da sua profissão.

$\mathrm{Na}$ ação de indenização pelo segundo tipo (obrigação de resultado), ocorre culpa presumida quando a cirurgia ou ato médico não atinge o resultado esperado. A vítima deve comprovar apenas o dano e o nexo causal. Para se exonerar, o médico deverá provar a ocorrência de alguma das causas excludentes de responsabilidade, que serão relacionadas adiante.

O contrato médico é tipicamente de meio e não de resultado. Contudo, algumas modalidades geram discussão a respeito da natureza da obrigação gerada, se de meio ou de resultado.

Sobre a cirurgia estética, apontam Couto Filho e Souza (2002, p. 18-19): 
Há uma corrente que norteia o entendimento de que a obrigação na cirurgia estética deve ser considerada de resultado e, portanto, aplicável a teoria subjetiva, mas com culpa presumida e, por conseguinte, com a inversão do ônus da prova.

Outra corrente, entrementes, sustenta tratar-se de obrigação de meio, igualmente às demais especializações médicas, tendo em vista que as intervenções cirúrgicas estéticas, da mesma forma que quaisquer outras cirurgias e tratamentos médicos, são suscetíveis às mais diferentes intercorrências que independem do atuar médico.

Com todo o respeito às posições em contrário, nos filiamos à corrente que entende ser a obrigação estética de meio e, conseguintemente, só haverá o dever de indenizar mediante a comprovação de culpa.

Outros autores apontam que a cirurgia estética pode ser classificada em reparadora e estética propriamente dita. $\mathrm{O}$ mesmo vale para as intervenções odontológicas, que podem ser reparadoras ou puramente estéticas. Veja-se Sebastião (1998, p. 31):

\begin{abstract}
A Medicina plástica (incluída a dentária) desenvolve-se sob dois enfoques distintos: reparadora (tanto a de reconstrução estética para restauração, como a complementar, para sanar defeito congênito), e a simplesmente estética, de cunho voluntário e ditada pela vaidade pessoal (também denominada cosmetológica). $\mathrm{Na}$ cirurgia eminentemente reparadora, como já dito, o contrato é o comum (apenas de meios), enquanto que na cirurgia simplesmente estética (e por isso voluntária), o contrato é misto, ou seja, de meios e de resultados.
\end{abstract}

Com relação à realização de exames de laboratório e radiológicos, entendese que o mais correto é considerá-los como obrigações de resultado e não de meio, ou seja, quando houver erro no resultado do exame divulgado considera-se que a obrigação não foi cumprida.

\title{
2.6. O dano e suas espécies
}

Para análise dos pedidos mais comuns nas ações de erro médico, propõe-se a classificação dos danos em quatro espécies: físicos, estéticos, morais e materiais.

Os danos físicos ou corporais estão relacionados à perda de algum órgão, função ou sentido, invalidez da vítima, agravamento do estado de saúde, etc. A indenização normalmente é pedida em razão do tipo e da extensão da lesão, fixando-se um valor compensatório pela perda sofrida.

Observa-se que os danos físicos podem gerar danos estéticos, morais e materiais, casos em que existirão outras indenizações a serem tratadas separadamente. 
Os danos estéticos são caracterizados pela ofensa direta à integridade física da pessoa, causando deformações, marcas ou defeitos. Diniz (2008, p. 80) conceitua o dano estético como:

Toda alteração morfológica do indivíduo que, além do aleijão, abrange as deformidades ou deformações, marcas e defeitos, ainda que mínimos, e que impliquem sob qualquer aspecto um afeiamento da vítima, consistindo numa simples lesão desgostante ou num permanente motivo de exposição ao ridículo ou de complexo de inferioridade, exercendo ou não influência sobre sua capacidade laborativa.

Os danos morais se caracterizam pela angústia, dor e sofrimento causados à pessoa. Por exemplo, um exame que diagnostica erroneamente uma doença grave e por isso causa sofrimento ao paciente. Neste caso não há qualquer lesão física ou estética, mas pode haver dano moral.

Por fim, existem os danos materiais, chamados também de patrimoniais. Eles podem decorrer dos danos físicos ou estéticos sofridos, bem como de quaisquer falhas ou defeitos na prestação dos serviços médicos.

Os danos materiais são divididos em duas subespécies: danos emergentes e lucros cessantes. Os danos emergentes consistem na soma dos prejuízos patrimoniais que a vítima sofreu em razão do ato ilícito. Por exemplo: devolução do valor pago pela operação ou diagnóstico errado, novos exames para diagnosticar o mal causado ou agravado pelo erro médico, pagamento de tratamento médico e psicológico, cirurgias plásticas, próteses, medicamentos e outros.

Já os lucros cessantes consistem naquilo que a vítima deixou ou deixará de receber em conseqüência do ato ilícito. Normalmente consistem no pagamento de uma pensão pelo tempo em que a pessoa ficou sem trabalhar ou, no caso de incapacidade, pelo restante da vida.

\subsection{Culpa lato sensu, dolo e culpa stricto sensu}

A apuração de conduta irregular por parte do médico, seja ilícito civil, penal ou infração administrativa, exige a demonstração de que o profissional agiu com culpa e que em razão desta culpa foi causado algum tipo de dano ao paciente.

A culpa em sentido amplo (lato sensu) possui duas modalidades: dolo e culpa em sentido estrito (stricto sensu).

Dolo é a vontade livre e consciente de provocar determinado resultado. Por exemplo, o médico que intencionalmente lesiona um paciente ou provoca um aborto fora das hipóteses autorizadas pela lei.

A culpa stricto sensu divide-se em três modalidades: negligência, imprudência e imperícia. Em síntese: negligência é a desatenção ou falta de cuidado 
razoável; imprudência é a assunção de riscos de forma desnecessária; imperícia é a falta de habilidade técnica para exercer determinada atividade ou realizar determinado ato.

No âmbito penal, a distinção entre dolo e culpa stricto sensu é importante para classificar a conduta como crime doloso ou culposo. Já nos âmbitos civil ou administrativo, pode servir para avaliar o grau de responsabilização do profissional.

\subsection{Nexo causal}

$\mathrm{Na}$ lição de Melo (2008, p. 46), "O nexo causal é a relação de causa e efeito que liga o dano ao causador (responsabilidade subjetiva) ou ao responsável pela atividade (responsabilidade objetiva)"

O estabelecimento do nexo causal pode parecer simples à primeira vista, porém é uma das matérias que mais geram polêmicas e discussões no mundo jurídico. Os conceitos de causa e efeito possuem suas origens na própria natureza e suscitam discussões profundas também no terreno da Filosofia.

Fazendo-se uma primeira e superficial análise, causa é um acontecimento que gera determinado resultado. Raciocinando-se inversamente, para que um fato seja considerado causa deve-se verificar se, não ocorrendo tal fato, o resultado também não ocorreria.

Entretanto, diante de uma multiplicidade de causas, nem sempre é fácil de se determinar qual ou quais delas foram relevantes ou suficientes para gerar o resultado. Melo (op. cit., p. 47), citando o magistrado Sérgio Cavalieri filho, observa que:

Quando o resultado decorre de um fato simples, a questão não oferece a menor dificuldade, porquanto a relação de causalidade é estabelecida de maneira direta entre o fato e o dano" Como, nem sempre, nas relações jurídicas, as coisas se mostram com tamanha simplicidade, acresce o ilustre autor que "o problema torna-se um pouco mais complexo nas hipóteses de causalidade múltipla, isto é, quando há uma cadeia de condições, várias circunstâncias concorrendo para o evento danoso, e temos que precisar qual delas é a causa real do resultado.

As causas múltiplas, também chamadas de concausas, podem ser sucessivas ou concomitantes. Na primeira hipótese, uma causa produz danos sucessivos, sendo que os últimos são produzidos pelos antecedentes. Já na segunda hipótese, diversas causas concorrem para produzir um único dano. Podem ocorrer também situações em que diversas causas produzem diversos danos sucessivos, gerando uma dificuldade ainda maior na apuração.

Existem diversas teorias que buscam resolver a questão da causalidade múltipla, seguindo-se as três mais importantes. 
A teoria da equivalência das condições, também chamada teoria da equivalência dos antecedentes ou teoria da conditio sine qua non considera como causa qualquer das condições que concorreu para o resultado, não se questionando qual delas foi mais ou menos eficaz para a produção do evento danoso. A equivalência significa que, suprimida qualquer uma destas causas, o evento danoso não se verificaria.

A principal crítica a esta teoria é que ela permite uma regressão do nexo causal ao infinito. Assim, o responsável pelo dano causado em um acidente de trânsito não seria apenas o motorista que dirigiu o veículo com imprudência, mas também quem lhe vendeu o automóvel, quem o fabricou e assim por diante, o que pode gerar conclusões absurdas.

A segunda teoria é a da causalidade adequada, segundo a qual não existe equivalência entre as condições que concorrem para o evento, devendo ser considerada causa apenas aquela que for decisiva e adequada para a produção do resultado.

Nos dizeres de Couto Filho e Souza (2008, p. 9-10):

Em sede de responsabilidade civil, não há que se falar em equivalência das condições, sendo que será a causa do resultado, dentre as tantas condições que existam apontando para a produção do dano, somente aquela que tiver interferência decisiva na produção do evento, sem olvidar, no entanto, que deve ser realizada a análise em abstrato, ou seja, se a condição determinante para a obtenção do resultado danoso é, em abstrato, adequada à produção do mesmo.

Por último, a teoria do dano direto e imediato, também chamada de teoria da relação causal imediata ou teoria da interrupção do nexo causal, considera como causa o fator que tenha produzido diretamente e mais proximamente o resultado, de modo que a causa mais próxima exclui a mais remota.

\subsection{Excludentes da responsabilidade}

No caso da responsabilidade subjetiva ou contratual, o profissional pode se eximir do dever de indenizar quando demonstrar a inexistência do dano, o cumprimento do contrato, ausência de culpa ou exclusão do nexo de causalidade. Se a obrigação for de meio, o réu deverá comprovar que o ato foi realizado dentro das regras técnicas da profissão médica (ou seja, que não houve negligência, imprudência ou imperícia); se a obrigação for de resultado, deverá demonstrar que a intervenção atingiu o objetivo esperado (ou seja, que o contrato foi devidamente cumprido e que não houve dano).

Nos casos em que houver responsabilidade extracontratual, deverá o profissional comprovar a inexistência do dano, exclusão do nexo causal ou ainda ausência de culpa, esta também nas modalidades negligência, imprudência ou imperícia. 
No tocante à responsabilidade objetiva, que prescinde da demonstração de culpa, os fornecedores de serviços (hospitais, clínicas, laboratórios, etc.) somente se desobrigam do dever de indenizar caso demonstrem a inexistência do dano, ausência de defeito no serviço ou exclusão do nexo de causalidade.

Existem diversos fatores excludentes do nexo causal, os quais valem para todos os tipos de responsabilidade mencionados: fato exclusivo da vítima, fato concorrente da vítima, fato de terceiro, caso fortuito e força maior.

O fato exclusivo da vítima, que também pode ser chamado de culpa exclusiva da vítima, ocorre quando esta, por meio de determinado comportamento, provoca de forma exclusiva o dano.

Já no fato concorrente da vítima, existe uma conduta inadequada tanto do médico como do paciente, mediante atos independentes. A solução que se adota é repartir os danos de acordo com a parcela de responsabilidade de cada um no evento danoso. A culpa concorrente da vítima não exclui a responsabilidade, porém leva a uma redução do quantum indenizatório. Tal hipótese encontra-se prevista no art. 945 do Código Civil. ${ }^{9}$

Outra das possibilidades de ruptura do nexo causal é o fato de terceiro. Terceiro, como o nome sugere, é aquele que não possui qualquer vínculo com o suposto causador do dano ou com a vítima. Não se incluem nesta categoria os subordinados ou auxiliares do médico, que devem trabalhar sob supervisão constante deste (sob pena de culpa in eligendo ou in vigilando).

As últimas duas excludentes do nexo causal são os denominados caso fortuito e força maior. Na maior parte das legislações, estes termos são colocados juntos em seus textos, entretanto existe corrente doutrinária (Couto Filho, Souza e Rocha) que considera o caso fortuito como sendo aquele que se mostra imprevisível e inevitável, enquanto a força maior pode ser previsível, porém ainda assim é inevitável, como, por exemplo, os fenômenos da natureza.

A exclusão da responsabilidade nas hipóteses de caso fortuito e de força maior encontra-se prevista no art. 393 do Código Civil. ${ }^{10}$

$9 \quad$ Art. 945 do CC: "Se a vítima tiver concorrido culposamente para o evento danoso, a sua indenização será fixada tendo-se em conta a gravidade de sua culpa em confronto com a do autor do dano."

10 Art. 393 do CC: "O devedor não responde pelos prejuizos resultantes de caso fortuito ou força maior, se expressamente não se houver por eles responsabilizado. Parágrafo único. O caso fortuito ou de força maior verifica-se no fato necessário, cujos efeitos não era possivel evitar ou impedir." 


\subsection{A importância da prova na apuração dos fatos}

Nas ações civis, da mesma forma que nas demais esferas de responsabilidade, percebe-se uma grande dificuldade em determinar com exatidão se o médico foi realmente negligente, imprudente ou imperito, ou se o dano decorreu de circunstâncias outras.

Por vezes os advogados dos autores descrevem de forma exagerada os danos sofridos e as evidências de má conduta médica, enquanto os defensores da parte contrária, fundamentados em obras científicas e pareceres de especialistas, alegam que seus clientes nunca se afastaram dos procedimentos corretos.

Sobre o ônus da prova, Theodoro Junior aponta:

A culpa do médico, pela natureza do contrato que firma com o cliente, somente será configurada quando os seus serviços tiverem sido prestados fora dos padrões técnicos. Por isso, o fato constitutivo do direito de quem pede indenização por erro médico se assenta no desvio de conduta técnica cometido pelo prestador de serviços. Como esse desvio é uma situação anormal dentro do relacionamento contratual não há como presumi-lo. Cumprirá ao autor da ação proválo adequadamente (CPC, art. 333, I).

Na verdade, o serviço técnico do médico, com zelo e adequação, vem a ser a própria prestação contratual. Logo, quando o paciente se diz vítima de erro médico, na verdade está apontando o inadimplemento da prestação devida. Provar a culpa do médico, então, não é demonstrar apenas o elemento psicológico ou subjetivo da responsabilidade civil. É provar o inadimplemento mesmo da prestação devida pelo médico. E em qualquer ação de indenização por responsabilidade contratual, cabe sempre ao autor o ônus de provar o inadimplemento do réu. O que se dispensa, nos contratos de resultado, é a prova da culpa, nunca a do inadimplemento e a do dano.

A conduta irregular do médico é a um só tempo o inadimplemento e a culpa, razão pela qual o autor não se desobriga do ônus processual da prova senão comprovando a conduta culposa do médico. Sem a configuração desse tipo de conduta, jamais se admitirá como não cumprido o contrato de serviços médicos, salvo, é claro, nas hipóteses excepcionais de contratos médicos de resultado, a que já se aludiu, quando bastará ao paciente provar o dano e o nexo causal.

Quando existe prova segura de procedimento irregular, como, por exemplo, uma radiografia que acusa um material cirúrgico esquecido no corpo do paciente, as evidências são claras, pouco havendo para discutir. O problema surge quando não há este tipo de elemento nos autos.

A prova do erro médico muitas vezes é quase impossível para o paciente supostamente lesado, principalmente por causa da dificuldade que este enfrenta para obter documentos e testemunhas. 
Existe uma complexidade técnica nos procedimentos que é quase inteiramente desconhecida aos leigos. Tais procedimentos são muitas vezes realizados por uma equipe, dentro de um estabelecimento de saúde, sendo que quando ocorre algum erro os membros desta equipe tendem a ficar em silêncio ou procuram justificar suas ações. Acrescente-se a tudo isto o tempo que por vezes ocorre entre o evento danoso e a propositura da ação, o que dificulta ainda mais a colheita e realização de provas.

A medicina não pode ser considerada uma ciência inteiramente exata. De fato, as atitudes dos médicos e seus auxiliares muitas vezes baseiam-se em probabilidades, em decisões tomadas sob forte pressão e até mesmo cansaço físico e psicológico.

Não se pode presumir que, no exercício normal de sua profissão, o médico pretenda causar algum dano ao paciente. E, mesmo que tenha errado, é raro que ele admita tal fato em um processo judicial ou administrativo.

Os principais tipos de provas previstos no Código de Processo Civil são: depoimento pessoal, confissão, prova documental, prova testemunhal, prova pericial e inspeção judicial. Além disso, a lei processual permite o uso de quaisquer outros meios, desde que moralmente legítimos. ${ }^{11}$

O depoimento pessoal consiste na tomada de declarações em audiência de qualquer das partes do processo e pode ser determinado pelo juiz de ofício ou a pedido da parte contrária (art. 342 do CPC). As perguntas são feitas somente pelo juiz e pelo advogado da parte contrária.

A confissão ocorre quando a parte admite a verdade de um fato, contrário ao seu interesse e favorável ao adversário (art. 348 do CPC). Pode ser judicial ou extrajudicial, espontânea ou provocada.

A prova documental normalmente é trazida pela parte interessada quando se manifesta no processo. Se acaso o documento estiver em poder da parte contrária, o juiz pode conceder um prazo para que esta o apresente ou justifique a recusa, sob pena de serem admitidos como verdadeiros os fatos que o solicitante do documento pretendia comprovar (art. 355 a 363 do CPC).

Um dos documentos mais importantes dentro dos processos judiciais e administrativos é o prontuário médico. O mesmo é definido na Resolução n. 1.638/2002 do Conselho Federal de Medicina como sendo:

O documento único constituído de um conjunto de informações, sinais e imagens registradas, geradas a partir de fatos, acontecimentos e situações sobre a saúde do paciente e a assistência a ele prestada, de caráter legal, sigiloso e científico, que possibilita a comunicação entre membros

\footnotetext{
" Art. 332 do CPC: "Todos os meios legais, bem como os moralmente legítimos, ainda que não especificados neste Código, são hábeis para provar a verdade dos fatos, em que se funda a ação ou a defesa. "
} 
da equipe multiprofissional e a continuidade da assistência prestada ao indivíduo.

A mesma resolução, em seu art. $5^{\circ}$ dispõe quais são os itens que devem constar obrigatoriamente do prontuário confeccionado em qualquer suporte, eletrônico ou papel:

a) Identificação do paciente nome completo, data de nascimento (dia, mês e ano com quatro dígitos), sexo, nome da mãe, naturalidade (indicando o município e o estado de nascimento), endereço completo (nome da via pública, número, complemento, bairro/distrito, município, estado e CEP);

b) Anamnese, exame físico, exames complementares solicitados e seus respectivos resultados, hipóteses diagnósticas, diagnóstico definitivo e tratamento efetuado;

c) Evolução diária do paciente, com data e hora, discriminação de todos os procedimentos aos quais o mesmo foi submetido e identificação dos profissionais que os realizaram, assinados eletronicamente quando elaborados e/ou armazenados em meio eletrônico;

d) Nos prontuários em suporte de papel é obrigatória a legibilidade da letra do profissional que atendeu o paciente, bem como a identificação dos profissionais prestadores do atendimento. São também obrigatórias a assinatura e o respectivo número do $\mathrm{CRM}$;

e) Nos casos emergenciais, nos quais seja impossível a colheita de história clínica do paciente, deverá constar relato médico completo de todos os procedimentos realizados e que tenham possibilitado o diagnóstico e/ou a remoção para outra unidade.

O prazo mínimo recomendado para armazenagem do prontuário médico é de dez anos, correspondente ao prazo prescricional das ações pessoais previsto no Código Civil.

A prova testemunhal consiste na oitiva de pessoas pelo juiz em audiência. Quando a matéria for incontroversa, já estiver comprovada por documentos ou somente puder ser comprovada por exame pericial, o juiz pode dispensar ou indeferir a inquirição de testemunhas.

A inspeção judicial consiste na possibilidade do juiz de ir até determinado local para inspecionar pessoas ou coisas, a fim de esclarecer sobre fato que interesse à decisão da causa (artigo 440 do CPC). É realizada de ofício ou a pedido das partes, sendo que o juiz pode se fazer acompanhar de um ou mais peritos. As partes sempre têm o direito 
de acompanhar a inspeção, devendo ser lavrado auto circunstanciado de tudo que for útil ao julgamento.

A última espécie de prova descrita no Código de Processo Civil, que consiste no cerne deste trabalho e será estudada com maiores detalhes no próximo item, é a pericial. Dificilmente se encontrará um processo por erro médico sem que seja determinada a realização de perícia, uma vez que a apuração da ocorrência ou não de tal erro depende de conhecimentos técnicos específicos que o juiz não possui.

Veja-se o que diz Theodoro Junior:

Nem sempre é possível um juízo rigoroso, preciso, sobre a falha técnica e seu nexo com a lesão ou dano. Os tribunais, por isso, adotam, às vezes, princípios antigos e universalmente aceitos como o da previsibilidade e o da razoabilidade. $\mathrm{O}$ julgador segue sua experiência da vida, e da observação do que comumente acontece pode chegar a juízos de valor sobre a conduta profissional, quando se mostre muito difícil uma conclusão puramente técnica sobre a causa da lesão.

O ideal, porém, é exigir o magistrado, sempre, a prova pericial, para obter esclarecimentos que, de ordinário, não se comportam na esfera de seus conhecimentos e que se sujeitam a regras técnicas específicas e complexas.

Isto não quer dizer que o juiz fique escravo do laudo pericial. O CPC é claro ao estatuir que "o juiz não está adstrito ao laudo pericial, podendo formar a sua conviç̧ão com outros elementos ou fatos provados nos autos" (art. 436).

\title{
2.11. A prova pericial
}

Nos dizeres de Moraes (2003, p. 594):

\begin{abstract}
A expressão perícia vem do latim e indica habilidade. É utilizada no sentido amplo para a diligência feita para esclarecer fatos. Significa pesquisa, exame, a verificação de fatos e deve ser feita por pessoa de reconhecida competência técnica no assunto.
\end{abstract}

É até possível que o juiz tenha o conhecimento técnico ou científico para esclarecer os pontos controvertidos no julgamento de determinada questão. Entretanto, entende-se que a ocorrência de tal situação não deve afastar a realização da perícia, uma vez que este tipo de prova serve também para dirimir eventuais dúvidas que o juiz possa ter, convencer as partes a respeito da decisão que será tomada e auxiliar os Tribunais superiores, que eventualmente poderão julgar recursos.

$\mathrm{O}$ art. 420 do Código de Processo Civil menciona três tipos de perícia: exame, vistoria e avaliação. Nas palavras de João Batista Lopes (2002, p. 131) exame "é 
a espécie de perícia que recai sobre coisas ou pessoas com a finalidade de verificação de fatos ou circunstâncias de interesse da causa"

A vistoria é uma inspeção realizada em bens imóveis e a avaliação é a fixação ou estimação do valor de mercado de coisas móveis ou imóveis. Ambas, por possuírem finalidades especificas, não serão abordadas neste trabalho.

Já o parágrafo único do referido art. 420 traz algumas hipóteses em que o juiz pode negar a realização da perícia:

a) quando a prova do fato não depender do conhecimento especial de técnico;

b) quando for desnecessária em vista de outras provas produzidas;

c) quando a verificação for impraticável.

$\mathrm{Na}$ opinião de Lopes, sempre que o juiz puder, de forma mais simples ou menos onerosa, apurar a veracidade das alegações das partes, deverá evitar a realização da prova pericial e valer-se de outros elementos para formar sua convicção.

Na prática, porém, verifica-se que isso raramente ocorre. As questões postas em juízo pelas partes são tão complexas e suas versões dos fatos tão divergentes que a prova pericial se torna indispensável, vindo a se somar com as demais.

Prossegue-se com as definições de perito. Para Wambier, Almeida e Talamini (2006, p. 443), o perito "é um especialista em determinado ramo do saber, técnico ou científico, convocado como auxiliar da justiça para atuar no processo onde este meio de prova é admissível"

Em alguns casos, não se exige que o perito seja letrado ou tenha curso superior, mas que tenha conhecimento sobre a área em questão. Por exemplo, um mecânico pode servir como perito em caso de danos causados a veículo.

Em outros, entretanto, é necessária e praticamente obrigatória especial qualificação. Tratando-se de perícia de natureza médica, doença física ou mental, é essencial que o perito seja médico ou profissional com formação ou especialização relacionadas ao objeto da perícia.

O perito é alguém de confiança do juiz e pode ser nomeado livremente. Por ser considerado auxiliar da justiça, assume responsabilidades perante o juízo, não podendo apresentar qualquer dos motivos de suspeição ou impedimento com as partes, por exemplo vínculo de amizade íntima, inimizade capital, relação comercial, parentesco até segundo grau, interesse na causa, etc. (arts. 134 e 135 do CPC).

Assistentes técnicos são profissionais nomeados pelas partes que podem acompanhar os trabalhos do perito e eventualmente realizar seus próprios pareceres, 
criticando ou apoiando as conclusões do perito oficial. Por serem de confiança das partes e contratados por estas, não estão sujeitos a impedimento ou suspeição (art. 422 do CPC).

Em razão dos peritos terem a mesma formação profissional e muitas vezes a mesma especialização dos investigados, isto leva a uma importante discussão a respeito da possibilidade de corporativismo dos profissionais da medicina na realização das perícias.

Kfoury Neto (2002, p. 69), preocupando-se com o assunto, discorre:

Evidentemente, há natural tendência dos médicos ao exame mais tolerante do ato culposo, atribuído a colega seu. Tal afirmativa não encerra nenhum intuito de reprovação genérica ou acusação infundada. Apenas se quer dizer que o médico, ele próprio convicto de que deseja somente o melhor para o enfermo sob seu cuidado, busca automaticamente explicação científica (ou fática) para o erro do demandado. Custa-lhe admitir que o colega foi imperito, imprudente ou negligente. Prefere-se, por isso mesmo, utilizar expressões como "intercorrência", "acidente" "complicação" "fatalidade" ou "mau resultado"

Mas os médicos - como já dissemos erram. E, quando esse desvio chega ao Judiciário, é preciso que um perito, também médico, preferencialmente atuando na especialidade considerada, identifique com clareza o erro.

Aí surgem as dificuldades mencionadas linhas atrás. Laudos inconclusivos, dúbios, tergiversantes, contendo meias-verdades, reveladores do receio de "condenar o colega"

Melo (2008, p. 172) concorda com tais assertivas, acrescentando:

A experiência demonstra que o laudo técnico deve ser recebido com a devida cautela, pois a opinião em que se louva o perito, tende a isentar o colega pelo ato incriminado, sob a inspiração daquilo que os irmãos Mazeraund denominaram "esprit de corps" ou solidariedade profissional. $[\ldots]$

Felizmente, o magistrado não está adstrito ao laudo pericial. Muito embora se possa afirmar que o mesmo é leigo em assuntos médicos, ele está autorizado a formar sua convicção lastreada em outros elementos constantes do processo, até mesmo divergindo da conclusão pericial. A razão lógica dessa autorização legal é muito simples, pois decorre da independência que deve se revestir a elevada função do juiz. Admitir que o juiz deva subordinar sua decisão à conclusão do laudo pericial seria o mesmo que dizer que a prestação jurisdicional seria prestada pelo perito, sendo ele, então, o verdadeiro juiz da causa. E isso, evidentemente, seria um tremendo contra-senso.

Para Moraes (2003, p. 459), o espírito de corpo pode até existir, porém jamais para acobertar os médicos negligentes, imprudentes e imperitos, e sim para fortalecer o médico idôneo, competente, dedicado, assim como sua classe. 
Entende-se que deve ser aplicado o brocardo latino iudex est peritum peritorum, vale dizer: "o juiz é o perito dos peritos" Cabe ao julgador, com base em sua experiência profissional e de vida, analisar todos os elementos dos autos, e não somente a perícia, para chegar a uma decisão verdadeiramente justa.

\subsection{Procedimentos da perícia e elementos do laudo}

Normalmente na petição inicial e na contestação as partes se limitam a protestar genericamente pela produção de todas as provas em direito admitidas. Somente no saneamento do processo, após a fixação dos elementos controvertidos, é que o juiz define ou não a necessidade da perícia.

Deferida a prova pericial, o juiz nomeia o perito, fixa o prazo para a entrega do laudo e possibilita às partes formular quesitos e indicar assistentes técnicos.

Os quesitos são indagações que o juiz e as partes formulam para serem respondidas pelo perito e, eventualmente, pelos assistentes técnicos. Leciona Dinamarco sobre os quesitos (2004, p. 593-594):

Eles devem guardar pertinência com a causa e com os pontos a provar, fixados pelo juiz na audiência preliminar (art. 331, $\S 2^{\circ}$ ). Não são admissíveis quesitos que transcendam a matéria de fato sujeita à perícia, como os que indagam sobre fatos incontroversos ou a serem provados por testemunhas mediante documentos; o juiz deve indeferir tais quesitos por impertinência (art. 426, inc. I). Também não é lícito pedir conclusões jurídicas ao perito, ao qual incumbe apenas, como auxiliar da Justiça, informar o juiz sobre matéria de fato, para que este conclua; eventual resposta a quesitos desta ordem é inócua e não deve ser considerada pelo julgador, que é titular executivo do poder de decidir.

As despesas com a perícia cabem à parte que a requereu, ou então ao autor, quando requerida por ambas as partes. Em casos de assistência judiciária gratuita, no estado de São Paulo a perícia normalmente é realizada pelo IMESC ou então por perito de confiança do juízo que aceite fazê-la gratuitamente ou concorde em receber sua remuneração pelo vencido, ao final da causa.

Em seus trabalhos, o perito deverá realizar exames, análises de documentos, investigações, pesquisas e diligências, apresentando ao final em juízo um documento escrito chamado laudo pericial.

Moraes (2003, p. 595) fornece uma boa definição da palavra laudo:

Laudo é a expressão latina empregada genericamente para denominar o documento escrito exarando parecer ou relatório dos peritos. Pode limitar-se a fornecer uma informação, ser conclusivo ou ser um esclarecimento de 
ordem técnica, dependendo da natureza da perícia. Desse fato decorre a expressão laudo pericial.

Como visto, o juiz não está obrigado a seguir as conclusões do laudo, porém deverá indicar na sentença os motivos de seu convencimento. $O$ afastamento das conclusões do laudo deve estar apoiado em fundamentos consistentes, notadamente em outros elementos probatórios existentes no processo.

Para fins de organizar o estudo das questões discutidas, clareza de exposição e justificativa de suas conclusões, os laudos periciais apresentados nos processos judiciais devem conter determinados elementos. A ausência ou omissão destes elementos dificulta o trabalho do juiz e das partes, podendo ainda demonstrar falta de diligência do perito.

Alcântara (2006, p. 15) leciona que em todos os laudos devem constar as seguintes partes:

a) Preâmbulo (preambulus) é a introdução, que se refere ao local da perícia, à data e hora, à autoridade solicitante, aos peritos designados, à identificação da pessoa ou do objeto a ser periciado, ao exame a ser realizado e aos quesitos a serem respondidos.

b) Histórico ou comemorativo, que é um relato completo do fato, justificador do pedido da perícia.

c) Descrição (visum er repertum), que encerra, com todos os detalhes, os achados objetivos e subjetivos dos exames realizados.

d) Discussão, que é o debate, a confrontação de hipóteses, as possíveis controvérsias de cada caso.

e) Conclusão, que é a ilação tirada com a análise dos dados descritos e discutidos, a posição final procurada pelo solicitante da perícia.

f) Respostas aos quesitos, que permitem a formação de juízos.

diferentes:

O professor Moraes (2003, p. 595-596) fornece algumas definições

a) Cabeçalho nome completo do profissional, sua qualificação técnica, quem nomeou ou solicitou a perícia e seu objetivo.

b) Identificação do indivíduo, corpo ou objeto descrição do indivíduo com indicação dos documentos que permitem sua identificação e, se for o caso, do corpo ou de objeto em exame. 
c) Histórico resumo dos acontecimentos, indicando com clareza e destacando a data de cada ocorrência e as conseqüentes alterações causadas.

d) Exame físico - completo e minucioso do ser humano vivo ou morto, juntando os exames complementares pedidos ou apresentados. Incluem-se aqui todos os exames necessários para o diagnóstico preciso.

e) Discussão nela, o perito pode confrontar os dados observados com os da literatura e interpretar ou mesmo elaborar conjecturas especulativas que permitam a interpretação do fato ou do fenômeno.

f) Conclusões aqui o perito deve expor, de maneira articulada, os resultados finais do parecer.

g) Respostas aos quesitos aqui se espera concisão e objetividade, devendo o perito responder laconicamente cada item. Os laudos de corpo de delito indagam de forma sistemática os quesitos da lei.

Tais autores observam que o laudo, embora seja opinativo, não pode ter conclusões jurídicas, pois estas cabem ao juiz. Não cabe ao perito, por exemplo, dizer se a ação deve ser julgada procedente ou não. Mas as respostas e análises feitas devem ser objetivas e tocar diretamente os pontos indagados, procurando identificar com clareza se o médico ou profissional de saúde cometeu ou não erro, quais os danos físicos observados, se os danos decorreram da conduta do médico, etc. Também é aconselhável que o perito preste outras informações pertinentes que tiver, ainda que fora do âmbito estrito dos quesitos, mas sempre com relação à causa e dentro dos limites de sua função auxiliar.

Após a entrega do laudo, as partes devem se manifestar sobre o mesmo e, caso queiram, juntar os pareceres de seus assistentes técnicos.

As partes podem fazer críticas ao laudo oficial ou concordar com o mesmo. Quesitos suplementares somente são admitidos durante as diligências e antes da entrega do laudo, porém excepcionalmente se admitem pedidos de esclarecimentos, desde que corretamente fundamentados.

Quando, após a entrega do laudo oficial, o juiz não se sentir suficientemente seguro para decidir e entender que as questões não foram suficientemente esclarecidas, a lei lhe dá a faculdade de determinar uma nova perícia. ${ }^{12}$

12 Art. 437 do CPC: "O juiz poderá determinar, de oficio ou a requerimento da parte, a realização de nova pericia, quando a matéria não lhe parecer suficientemente esclarecida." 
3. Método

\subsection{Conjunto pesquisado}

A pesquisa foi realizada no período de junho de 2008 a março de 2009. Foram examinados cerca de duzentos processos judiciais de responsabilidade civil por alegado erro médico, obtidos junto ao Departamento Jurídico de Defesa Profissional da Associação Paulista de Medicina, entidade federada da Associação Médica Brasileira, localizada na cidade de São Paulo. Destes, selecionaram-se quarenta e seis processos iniciados a partir do ano de 1997, que continham laudos periciais já realizados e relatados.

\subsection{Dados coletados dos processos}

A coleta de dados foi feita mediante pesquisa documental, examinando-se as principais peças dos processos, a saber: petições iniciais, contestações, quesitos formulados aos peritos para resposta, laudos entregues, eventuais pedidos de esclarecimentos, laudos complementares e, quando existentes, as sentenças de primeiro grau e acórdãos proferidos em grau de apelação. $\mathrm{O}$ estudo foi orientado pelas seguintes técnicas de análise:

* Análise descritiva. As informações constantes de cada processo foram submetidas à tabulação a fim de caracterizar o conjunto analisado e verificar se os laudos continham todos os elementos recomendados e descritos na parte teórica. Os dados colhidos nesta parte foram:

a) número do processo;

b) cidade em que tramita o processo;

c) se os autores fizeram pedido de justiça gratuita;

d) quais os problemas alegados pelos autores;

e) se o laudo foi realizado por perito do juízo ou do IMESC;

f) número de páginas do laudo;

g) se o laudo continha introdução e histórico do caso;

h) se o perito realizou exame físico geral e especial no periciando;

i) se o laudo apresentou análise dos documentos dos autos judiciais;

j) se o laudo continha discussão fundamentada;

k) se o laudo apresentou conclusão clara;

1) se o laudo respondeu todos os quesitos das partes;

m) se houve pedido de esclarecimentos ou de laudo complementar. 
* Análise crítica. Em complemento à análise descritiva, buscou-se um exame sistemático e qualitativo dos processos e dos laudos periciais. Foram examinados os seguintes pontos:

a) aspectos relevantes dos processos;

b) quais os tipos de dano mais freqüentemente alegados pelos autores;

c) quais os pedidos de indenização mais comuns, dentro da seguinte classificação: danos físicos, danos morais, danos estéticos, devolução do valor pago, despesas médico-hospitalares e/ou nova cirurgia, lucros cessantes e/ou pensão e outras despesas (específicas para cada caso);

d) tempo decorrido entre o ajuizamento da ação e a sentença de primeiro grau;

e) se os laudos apresentaram todos os elementos recomendados;

f) como os peritos fundamentaram suas conclusões;

g) a importância de os peritos serem ou não especialistas para elaboração dos laudos e acolhimento pelo juízo;

h) quais os resultados das ações, ou seja, como foram julgadas até o momento em que foram colhidos os dados;

i) relevância dos laudos nas sentenças e acórdãos;

j) outras partes apresentadas pelos peritos nos laudos (por exemplo: fotografias, exposições teóricas, etc.);

k) observações e sugestões para elaboração dos laudos periciais.

\section{Resultados}

4.1. Descrição geral dos processos e dos laudos periciais

Todos os processos foram instaurados na justiça estadual de São Paulo. Na comarca de São Paulo (capital) tramitaram 31 processos $(67,4 \%)$ e nas demais comarcas tramitaram 15 feitos $(32,6 \%)$.

Em 38 processos $(82,6 \%)$ os autores pediram os benefícios da justiça gratuita e apenas $8(17,4 \%)$ ingressaram com a ação sem tal pedido.

Os casos de erro em cirurgia não-estética foram $25(54,3 \%)$, sendo que destes 4 foram relativos a objetos esquecidos em pacientes e outros 3 com resultado morte. Erros de diagnóstico e/ou falhas no atendimento em hospitais/pronto-socorros foram alegados em 7 casos (15,2\%), sendo 4 com resultado morte. Cirurgias estéticas com resultado diverso do esperado consistiram em 6 casos $(13,0 \%)$. Por fim, restaram 8 casos $(17,4 \%)$ que, por combinarem dois ou mais tipos de erro, por sua complexidade ou particularidade, foram classificados na categoria outros. 
Quanto à elaboração, 27 laudos (58,7\%) foram realizados por peritos do IMESC, enquanto os 19 restantes $(41,3 \%)$ foram elaborados por peritos médicos particulares indicados pelo juízo.

O número de páginas de cada laudo variou entre 1 e 110 . O menor laudo continha apenas as respostas aos quesitos, enquanto o maior continha longa exposição teórica, sendo que algumas passagens não tinham qualquer relação com o tema do laudo. Excluindo-se tais laudos, a média ficou em 10,5 páginas por laudo, sendo que o valor mais freqüente foi de 4 páginas em oito dos laudos apresentados.

\subsection{Elementos específicos constantes dos laudos}

Do conjunto examinado, 44 laudos $(95,7 \%)$ continham introdução e histórico do caso, enquanto $2(4,3 \%)$ não os possuíam.

Em 32 casos $(69,6 \%)$ foi realizado exame físico geral e especial, em 6 $(13,0 \%)$ não houve qualquer menção e em $8(17,4 \%)$ o exame direto ficou prejudicado em razão da morte da parte periciada ( 7 pacientes morreram durante o ato médico e 1 morreu no decorrer da ação).

Em 41 laudos $(89,1 \%)$ o perito narrou ter examinado os documentos existentes no processo judicial, sendo que em 5 deles $(10,9 \%)$ nada foi mencionado.

26 laudos (56,5\%) apresentaram uma discussão fundamentada. Outros 12 $(26,1 \%)$ continham uma fundamentação parcial e $8(17,4 \%)$ não tiveram nenhum tipo de discussão ou fundamentação.

29 laudos $(63,0 \%)$ continham uma conclusão clara, e $17(37,0 \%)$ não a apresentaram. Nestes últimos, foram incluídos tanto os laudos que não tinham conclusão, como aqueles que deixavam de emitir a opinião do perito, e ainda os que continham frases como "dizer se houve ou não erro é missão privativa do juiz"

Houve resposta integral a todos os quesitos das partes em 33 casos $(71,7 \%)$. Em 9 casos (19,6\%) o perito não respondeu nenhum quesito, em 3 casos $(6,5 \%)$ respondeu apenas os quesitos de uma das partes, deixando de responder os da outra parte e em 1 caso $(2,2 \%)$ as partes não apresentaram quesitos.

Além das respostas aos quesitos faltantes, houve 28 processos em que foram pedidos esclarecimentos ou a realização de laudo complementar $(60,9 \%)$. Em 18 casos $(39,1 \%)$ não foram solicitados esclarecimentos.

\section{Discussão}

Durante a coleta de dados junto ao Departamento Jurídico de Defesa Profissional da Associação Paulista de Medicina foram examinados aproximadamente 
duzentos processos, porém muitos deles se encontravam na fase inicial ou aguardavam a vinda dos respectivos laudos, o que restringiu a obtenção de um número maior.

Dentre os que continham laudos, o processo mais antigo teve início em 1997 e o mais recente em 2007. Considerando que a obtenção dos dados terminou em março de 2009, verificou-se que dificilmente a vinda do laudo ao processo ocorre em menos de dois anos.

Não foi possível aferir com exatidão o tempo gasto pelos peritos para elaboração e entrega dos laudos, em razão da falta de elementos suficientes em alguns deles, tais como: data de retirada dos autos ou recebimento das principais peças e quesitos pelo perito, data do exame físico das partes, ausência de data no corpo do laudo, divergências entre a data constante do laudo e a efetiva entrega em juízo e outros.

Usou-se então como critério aproximado o tempo decorrido desde a entrega dos quesitos pelas partes (obtido nas respectivas petições) até a juntada do laudo aos autos, constatando-se diferenças significativas entre o tempo despendido pelos peritos do juízo e os do IMESC.

Para os peritos particulares indicados pelo juízo, o tempo mínimo para entrega do laudo foi de 1 mês e meio e o máximo de 2 anos e 6 meses, sendo o médio de 11 meses. Quando a perícia foi realizada pelo IMESC, o tempo mínimo foi de 2 meses e o máximo de 3 anos e 2 meses, sendo o médio de 1 ano e 4 meses.

Como se pode observar, os peritos do IMESC demoraram mais para entregar seus laudos do que os peritos do juízo. A hipótese mais provável para esta diferença, conforme a prática judicial, é que estes últimos possuem interesse em terminar o trabalho rapidamente para receberem seus honorários, enquanto aqueles se encontram em órgão oficial com grande volume de trabalho. Para que não haja maiores atrasos na prestação jurisdicional, o Estado deveria dotar o IMESC de recursos humanos e materiais.

Nem sempre a rapidez na entrega do laudo é uma garantia de qualidade. Houve um laudo entregue em dois meses que continha uma página e cujo conteúdo foi considerado inadequado e insuficiente. Alguns dos laudos que demoraram mais de dois anos para serem entregues não tinham fundamentação ou conclusão claras.

Não se conseguiu encontrar um critério uniforme utilizado pelos peritos para avaliar se o médico atuou ou não com negligência, imprudência ou imperícia, ou mesmo para a determinação do nexo causal. Trata-se de dificuldade já relatada na exposição a respeito das provas (itens 2.10 e 2.11 acima).

Os elementos da responsabilidade civil passíveis de apuração com maior grau de certeza foram os danos físicos, estéticos e materiais e as situações de evidente inobservância de regras técnicas.

Outro problema encontrado foi que em muitos casos não houve como se saber a especialidade dos peritos que elaboraram os laudos. Nos 46 processos, apenas 
20 peritos declararam ter a especialização necessária para o caso examinado, enquanto 26 não declinaram sua especialização. A incerteza a respeito da qualificação de mais da metade dos peritos criou dificuldades para analisar a relação entre a especialização destes e a aceitação dos laudos.

Com relação à pesquisa bibliográfica, não foram encontrados estudos que pudessem servir de comparação a este. Não obstante, verificaram-se dois estudos assemelhados, um na área de perícia contábil ${ }^{13} \mathrm{e}$ outro na área de psiquiatria forense,,$^{14}$ mas que tiveram limitada aplicação no presente.

\subsection{Comentários sobre os processos}

O primeiro item que chamou a atenção foi o número expressivo de pedidos de justiça gratuita. Conforme já apresentado no item 4.1, um percentual de $82,6 \%$ dos autores pediu os benefícios da justiça gratuita.

Com um percentual tão elevado de autores beneficiários da justiça gratuita, seria de se esperar que a grande maioria das perícias fosse realizada pelo IMESC, órgão público que realiza as perícias gratuitamente. Entretanto, o IMESC elaborou 58,7\% dos laudos periciais e os outros médicos indicados pelo juízo $41,3 \%$.

Para esclarecer esta situação, a análise dos documentos dos autos permitiu constatar que, nos casos de justiça gratuita, as perícias feitas por médicos do juízo foram pagas pelos réus, realizadas gratuitamente ou então sob a condição de serem pagas ao final pela parte vencida.

Embora sediado em São Paulo, capital, o IMESC não atuou somente em processos que corriam nesta cidade. Dos 31 processos da capital, os peritos do IMESC atuaram em $18(58,1 \%)$, enquanto em 13 foram nomeados peritos do juízo $(41,9 \%)$. Nos 15 processos de outras cidades, os peritos do IMESC atuaram em $9(60 \%)$ e os do juízo em $6(40 \%)$.

Outro dado que se destacou foram os tipos de dano alegados pelos autores: $54,3 \%$ dos processos trataram de erros em cirurgia não estética, $15,2 \%$ sobre erros de diagnóstico ou falha no atendimento, 13\% sobre resultados de cirurgia estética e 17,4\% referiram-se a outros assuntos.

A cirurgia estética, considerada como especialidade isolada, foi a modalidade que mais apresentou pedidos de reparação. O resultado foi semelhante a um estudo

13 SANTANA, Creusa Maria Santos de. A perícia contábil e sua contribuição na sentença judicial: um estudo exploratório. 1999. Dissertação (Mestrado) - Faculdade de Economia e Administração, Universidade de São Paulo, São Paulo.

14 RAMOS, Maria Regina Rocha. Estudo da concordância entre laudos psiquiátricos conclusivos de capacidade parcial de imputação e sentenças judiciais. 2002. Dissertação (Mestrado) Faculdade de Medicina, Universidade de São Paulo, São Paulo. 
realizado pelo CREMESP em 2007, ${ }^{15}$ o qual mostrou que a maior taxa de profissionais que sofreram processos judiciais (número de médicos especialistas processados, dividido pelo número de médicos especialistas em atividade, multiplicado pelo tempo de formado) no período de 2000 a 2006 pertenceu aos especialistas em cirurgia plástica.

Consideradas as classificações das outras modalidades de cirurgia relacionadas no estudo do CREMESP ( $3^{\mathrm{a}}$ cirurgia do trauma, $9^{\mathrm{a}}$ cirurgia geral, $11^{\mathrm{a}}$ pediátrica, $12^{\mathrm{a}}$ cardiovascular, $13^{\mathrm{a}}$ do aparelho digestivo, $20^{\mathrm{a}}$ da cabeça e pescoço, $24^{\mathrm{a}}$ vascular e $27^{\text {a }}$ torácica), estima-se que os pedidos de danos decorrentes de cirurgia devem superar as demais modalidades, conforme observado.

Para analisar quais os pedidos de indenização mais freqüentes, foram desconsideradas duas das ações que eram unicamente cautelares, uma vez que por sua natureza não apresentaram pedido condenatório.

O pedido mais comum em todas as ações, observando que cada uma delas poderia apresentar mais de um pedido, foi o de indenização por danos morais (100\%), seguido de lucros cessantes e/ou pedidos de pensão com 19 casos $(43,2 \%)$, despesas médico-hospitalares e/ou nova cirurgia com 17 casos $(38,6 \%)$, devolução de valores pagos com 9 casos $(20,5 \%)$, danos estéticos com 3 casos $(6,8 \%)$ e danos físicos com 2 casos $(4,5 \%)$. Outros pedidos estiveram presentes em 29 casos $(65,9 \%)$.

$O$ valor mais baixo pedido em sede de danos morais foi de 50 salários mínimos e o mais alto de 5.000 s.m. (não há limites para o que se pode pedir de indenização, ainda mais quando os autores são beneficiários da justiça gratuita). $\mathrm{O}$ valor mais pedido foi de 1.000 salários mínimos, com dez ocorrências, sendo que a média de valores ficou em 1.161 s.m.

O fato de terem sido pedidos valores elevados não implicou que fossem acolhidos pelo juízo. Conforme se verificou nas sentenças proferidas, o valor mínimo de condenação por danos morais foi de 14 salários mínimos e o valor máximo de 1.000 s.m., sendo que a média foi de 243 salários mínimos.

O tempo mínimo observado entre o ajuizamento da ação e a sentença de primeiro grau foi de 1 ano e 9 meses e o máximo de 6 anos e 5 meses, sendo o médio de 3 anos e 9 meses. A complexidade de cada caso em particular, a multiplicidade de partes, o número de processos em andamento na unidade judicial, a pauta de audiências e o tempo de apresentação dos laudos periciais, entre outros fatores, influem no tempo necessário para que uma causa seja julgada.

is CONSElHO REGIONAL DE MEDICINA DO ESTADO DE SÃO PAULO. Denúncias e processos relacionados ao exercício profissional da medicina no Estado de São Paulo no período de 2000 a 2006. São Paulo, 2007. 
Após a sentença de primeiro grau, houve recurso em todos os processos, que foram encaminhados ao Tribunal de Justiça de São Paulo para julgamento. Apenas cinco recursos haviam sido julgados até a coleta de dados. O tempo para que o recurso fosse julgado pelo Tribunal variou de 1 ano e 5 meses a 6 anos e 9 meses, com uma média de 4 anos e 2 meses (lembre-se que o número ainda é baixo para se aferir uma média segura).

\subsection{Análise crítica dos conteúdos dos laudos}

Os dois pontos principais examinados consistiram em saber se os laudos apresentaram todos os elementos recomendados e se auxiliaram corretamente na tomada de decisões pelos juízes.

Os elementos iniciais do laudo são a introdução e o histórico. Ambos foram reunidos para fins de estudo, pois se observou que, na prática, muitos peritos colocam o histórico dentro da introdução e vice-versa. Nesta parte do laudo, o perito deve fornecer ao juiz a identificação da pessoa, um breve relato do caso e do problema posto em análise.

Apenas 2 laudos não apresentaram introdução ou histórico do caso. Tais laudos eram bastante sucintos, possuindo o primeiro deles apenas uma página e o segundo apenas três, sendo também considerados deficientes nos demais itens.

O exame físico geral e especial do paciente periciado foi mencionado em 32 laudos e em 6 deles não houve qualquer menção de sua realização. Os 8 exames restantes ficaram prejudicados em razão da morte do paciente, procedendo-se ao chamado exame indireto.

Considera-se essencial que o médico tenha contato direto com a parte periciada, pois nem sempre os documentos dos autos fornecem com exatidão os detalhes dos procedimentos realizados, tampouco eventuais seqüelas.

O exame dos documentos existentes no processo também deve ser mencionado expressamente pelo perito no laudo, a fim de dar suporte ao seu trabalho. Apesar disso, em 5 laudos $(10,9 \%)$ o perito não fez qualquer menção sobre ter ou não examinado os documentos dos autos.

O autor da ação na maioria das vezes não tem acesso aos documentos necessários para apuração dos fatos, cabendo ao réu trazê-los ou serem requisitados pelo juízo aos estabelecimentos de saúde. Um dos documentos essenciais é, sem dúvida, o prontuário médico.

Outro ponto importante a se notar é que nem sempre o perito judicial tem acesso ao conteúdo completo dos autos judiciais, pois estes costumam ficar armazenados no cartório.

Na maioria das varas judiciais observa-se que o perito nomeado pelo juízo, que recebe honorários pagos pelas partes, vem em cartório e retira os autos. Entretanto, quando a perícia é realizada em órgão oficial como o IMESC, por exemplo, o perito não 
tem meios ou recursos para ir a todas as varas judiciais e retirar os processos. Os cartórios então extraem cópias das principais peças dos autos e as encaminham ao órgão onde o perito trabalha.

Tal procedimento pode, eventualmente, não fornecer todas as cópias necessárias e uma visão completa das questões a serem apuradas no processo, cabendo ao perito, caso entenda necessário, solicitar informações complementares ao juízo, às partes ou aos estabelecimentos envolvidos.

Após expor todos os elementos examinados, o perito deve discutir e fundamentar adequadamente seu trabalho, mostrando ao juiz quais são os aspectos levados em conta para determinar se houve dano, qual a extensão deste, a culpa e o nexo causal.

Nos processos analisados foi verificado que 26 laudos $(56,5 \%)$ apresentaram uma discussão completa e fundamentada, $12(26,1 \%)$ possuíam uma fundamentação parcial e os 8 restantes $(17,4 \%)$ não tiveram discussão ou fundamentação.

O trabalho pericial deve ter também uma conclusão clara, a fim de auxiliar na decisão do juiz. O perito deve assumir uma posição e indicar ao magistrado se, no seu entender, houve ou não erro médico, ou ainda se é impossível determiná-lo.

Esta parte teve problemas semelhantes à anterior: 29 laudos $(63 \%)$ continham uma conclusão clara e 17 (37\%) não a apresentaram. Nestes últimos, como mencionado na exposição de dados, foram incluídos tanto os laudos que não tinham conclusão, como aqueles que se abstiveram de dar sua opinião.

Foram observados diversos laudos inconclusivos. Um deles, por exemplo, limitou-se a descrever os procedimentos, sem dizer se estavam corretos ou não e alegou que "a existência de incúria médica é questão de mérito" Outro afirmou que se tratava de "missão privativa do juiz ou dos Conselhos Regionais de Medicina" Alguns laudos não conseguiram esclarecer ou ajudar a esclarecer se houve erro na conduta médica prestada.

Ao final do laudo, o perito deve responder os quesitos formulados pelo juiz e pelas partes. Longas digressões devem ser evitadas nesta parte, pois já devem ter sido realizadas na parte da discussão.

Constatou-se que 33 laudos $(71,7 \%)$ o fizeram adequadamente, porém em 9 casos $(19,6 \%)$ o perito não respondeu nenhum quesito e em $3(6,5 \%)$ ele respondeu apenas os quesitos de uma parte, deixando de responder os demais.

Somando-se estes dois últimos valores, em mais de $25 \%$ dos casos os peritos simplesmente entregaram seus laudos sem atentar para as respostas às perguntas feitas no processo, o que certamente demandou atrasos no andamento para que tais omissões fossem sanadas.

Em 28 laudos $(60,9 \%)$ foi necessário acionar novamente o perito para responder os quesitos faltantes, prestar esclarecimentos ou realizar laudo complementar. Isto não quer dizer necessariamente que todos estes laudos apresentaram problemas. 
Muitas vezes a parte que vislumbra uma conclusão desfavorável procura buscar junto ao perito algum elemento que lhe favoreça.

A maioria das perícias, mesmo aquelas realizadas por médicos pertencentes a órgãos públicos, não teve uma redação precisa ou padronizada. Alguns peritos fizeram longas incursões teóricas, outros se limitaram a apenas responder os quesitos formulados pelas partes, outros ainda chegaram a se manifestar juridicamente sobre a causa.

Embora os problemas apresentados tenham sido descritos com maior ênfase, destaca-se que, combinando os percentuais de avaliação da discussão, conclusão e resposta aos quesitos formulados, em torno de 60 a $70 \%$ dos laudos cumpriram bem sua função de auxiliar na decisão do juiz e foram considerados satisfatórios. Os melhores laudos foram aqueles que, em vez de se limitarem a responder os quesitos formulados, forneceram informações úteis e adicionais, pertinentes às matérias examinadas.

Os outros 30 a $40 \%$ consistem em um percentual significativo, que poderá ser melhorado com algumas das sugestões a serem feitas no último item deste capítulo.

\subsection{Sentenças e acórdãos proferidos}

Nos 46 processos analisados, foram proferidas 24 sentenças. Destas, $14(54,2 \%)$ julgaram a ação improcedente, $9(41,6 \%)$ procedente em parte e $1(4,2 \%)$ inteiramente procedente. A única ação julgada inteiramente procedente possuía somente pedido de dano moral, enquanto as procedentes em parte possuíam vários pedidos e alguns deles foram acolhidos.

Averiguou-se como se deu a utilização dos laudos nestas sentenças judiciais. Para isso, tal utilização foi classificada em três níveis: integral (casos em que o juiz acolheu integralmente os elementos do laudo mesmo naqueles que não tinham uma conclusão clara, o magistrado fundamentou-se majoritariamente em alegações presentes no restante do trabalho pericial), parcial (quando o juiz acolheu parcialmente o laudo) e irrelevante (quando o juiz não acolheu o laudo).

Nas 24 sentenças proferidas, 19 acolheram integralmente o laudo (79,2\%), 4 parcialmente $(16,6 \%)$ e 1 não acolheu o laudo pericial $(4,2 \%)$. Esta única ação será descrita com detalhes adiante.

Houve apenas 5 acórdãos proferidos em segunda instância. Destes, 4 confirmaram as sentenças de primeira instância e 1 reformou a sentença que não havia acolhido o laudo e julgado a ação improcedente. Cabe aqui uma rápida exposição deste caso, porque envolve inclusive uma discussão a respeito da especialização dos peritos.

Tratava-se de ação segundo a qual a autora foi submetida a cirurgia de hérnia de disco cervical. Alegou que o médico lesionou a proteção da meninge, a traquéia e o esôfago na primeira cirurgia. Que não houve proteção adequada de sua cama pelo 
hospital, o que causou uma queda e complicação de seu estado de saúde. Relatou ainda a ocorrência de complicações e que ficou incapacitada para o trabalho.

O perito judicial afirmou que houve erro de técnica na primeira cirurgia e que o requerido não corrigiu o erro na segunda intervenção. Relatou dano físico, incapacidade laborativa total e permanente, danos estéticos e danos neuropsíquicos. Já o assistente técnico do médico réu alegou que não houve culpa deste e sim intercorrência relativa à migração do enxerto ósseo, provavelmente provocada pela queda da paciente do leito.

A sentença que não acolheu o laudo oficial fundamentou-se no parecer do assistente técnico do réu e de testemunhas, afirmando que o perito judicial não era especialista na área (neurocirurgia), ao contrário do assistente técnico.

No Tribunal de Justiça, os desembargadores converteram o julgamento em diligência para realização de nova perícia oficial por médico especialista em neurocirurgia. Este apresentou laudo que confirmou o nexo causal, porem afirmou considerar que houve apenas complicação de um procedimento cirúrgico de alto risco, que não consistiria em erro médico.

O acórdão não acolheu a afirmação do segundo perito de que não considerava erro uma complicação de procedimento cirúrgico de alto risco, por não estar fundamentada e por se tratar de mera opinião, insuficiente para descaracterizar o laudo técnico apresentado pelo primeiro perito judicial. Reconheceu a solidariedade da prestadora do plano de saúde, mas não do hospital, que somente prestou serviços de enfermagem, internação e infraestrutura. Entendeu que os tratamentos de fisioterapia e outros deveriam ficar a cargo do plano de saúde e concedeu à autora uma indenização por danos morais.

O caso é emblemático, pois os desembargadores que fizeram parte da turma julgadora concordaram apenas parcialmente com as alegações do segundo laudo, realizado por especialista. Fundamentaram-se eles no primeiro laudo realizado por não-especialista, o qual apontou que o réu não observou os cuidados necessários para a realização do procedimento cirúrgico.

Conclui-se desta análise das sentenças e acórdãos que, apesar das deficiências apresentadas por alguns dos laudos, são eles realmente importantes para a decisão judicial. Os laudos cuja utilização foi parcial acabaram sendo considerados pelos juízes como uma contribuição às demais provas realizadas. Eventuais lacunas decorrentes de deficiência técnica, possibilidade de corporativismo e falta de especialização dos peritos não foram suficientes para influir em desfavor dos autores.

\subsection{A questão da especialização dos peritos}

Deixou-se à parte esta questão, uma vez que nos 46 laudos estudados em apenas 20 os peritos se declararam especialistas na área periciada, enquanto 26 não 
fizeram tal declaração, gerando aqui um grau de incerteza sobre se eles possuíam ou não tal qualidade.

Em primeiro lugar, não se discute aqui sobre a imprescindibilidade do perito ter graduação em medicina ou então em área estritamente relacionada com o exercício da atividade médica (por exemplo, em casos de mau funcionamento de equipamento médico pode ser necessária perícia de engenharia biomédica).

Outrossim, entende-se ser bastante recomendável que o perito nomeado tenha algum tipo de especialização ou conhecimento específico da matéria periciada. Isto porque a medicina brasileira possui mais de 50 especialidades, cada uma podendo apresentar características próprias e peculiares.

Examinando apenas os 20 laudos oferecidos pelos especialistas, $13(65 \%)$ tiveram discussões e conclusões consideradas satisfatórias e 7 (35\%) insatisfatórias. Nos laudos cujos peritos não se declararam especialistas (reiterando que aqui existe incerteza, posto que não foi possível determinar as respectivas áreas de especialização), de um total de 26, $14(53,8 \%)$ tiveram discussões e conclusões satisfatórias e 12 (46,2\%) insatisfatórias.

Levando a análise para o campo das sentenças, nas 24 sentenças proferidas constatou-se que 8 tiveram seus laudos feitos por peritos que se declararam especialistas e 16 pelos demais.

Destes 8 laudos feitos por especialistas, $7(87,5 \%)$ foram totalmente acolhidos na sentença e 1 (12,5\%) foi parcialmente acolhido. Dos 16 laudos feitos pelos demais peritos, 12 (75\%) foram totalmente acolhidos na sentença, 3 (18,75\%) foram parcialmente acolhidos e 1 (6,25\%) não foi acolhido (este é o caso cujo julgamento foi revertido no Tribunal de Justiça).

Os números aqui apresentados, embora não sejam suficientes para fazer uma análise aprofundada, aliados à boa prática forense, sugerem que os laudos realizados por especialistas na área objeto da perícia tendem a ser melhor confeccionados e acolhidos pelos juízes.

\subsection{Observações e sugestões relativas à elaboração dos laudos periciais}

Aplicando-se a metodologia e os critérios evidenciados neste trabalho, resultaram algumas observações e sugestões para aperfeiçoar a elaboração dos laudos periciais.

A primeira recomendação, já exposta no item anterior, é que o perito nomeado seja especializado por meio de residência médica ou pelo menos tenha conhecimentos específicos, obtidos mediante a realização de cursos, participação em congressos, etc. dentro da área periciada.

Outra sugestão é que os conselhos regionais, universidades e sociedades de especialistas em medicina ofereçam um número maior de cursos de formação para a 
elaboração de laudos periciais em suas respectivas modalidades. Com isso, tais entidades podem também fornecer ao Poder Judiciário relações com os nomes destes peritos.

O cartório judicial deve dar atenção especial no sentido de disponibilizar todos os autos ao perito, e não somente as principais peças, pois a extração destas cópias muitas vezes é realizada de forma deficiente. Caso os autos permaneçam em cartório, recomenda-se a extração de cópias integrais às custas da parte interessada.

Os laudos periciais devem apresentar no mínimo as seguintes informações: a) introdução, contendo o objetivo da perícia e principais questões a serem analisadas; b) qualificação completa do perito; c) identificação da pessoa a ser examinada; d) histórico detalhado do caso obtido a partir do exame dos documentos constantes do processo, investigações, pesquisas e diligências; e) exame físico geral e especial ou, no caso de impossibilidade, a forma de realização da perícia indireta; f) discussão fundamentada; g) conclusão; h) respostas aos quesitos do juiz e das partes.

Por fim, o perito deve usar da maior clareza possível para apresentar seu trabalho, buscando não apenas responder os quesitos formulados, mas também fornecer informações adicionais úteis e pertinentes às matérias examinadas.

\section{Conclusão}

Nas ações de responsabilidade civil por alegado erro médico, o dano e o nexo causal estão sempre presentes como requisitos do dever de indenizar. Com exceção dos casos de responsabilidade objetiva e das obrigações de resultado, também se exige a demonstração de dolo ou culpa, esta nas modalidades negligência, imprudência ou imperícia.

Os principais tipos de provas que podem ser usadas para apurar o erro médico são: depoimento pessoal, confissão, prova documental, prova testemunhal, prova pericial e inspeção judicial.

O requisito mínimo recomendado para nomeação do perito que irá apurar o erro médico é que tenha graduação em medicina ou em área relacionada a esta. São desejáveis ainda especialização e conhecimentos específicos sobre perícia.

A execução dos trabalhos periciais não depende apenas da qualificação do perito, mas também da obtenção dos documentos necessários, sendo o principal deles o prontuário médico, além de exame físico da parte, pesquisas e diligências.

Caso os laudos do perito oficial e dos assistentes técnicos sejam antagônicos, ou quando entender que a matéria não lhe parece suficientemente esclarecida, o juiz pode se valer de perito desempatador.

Uma porcentagem significativa dos laudos periciais observados não apresentou elementos essenciais, tais como: introdução, exame físico geral e especial, exame dos documentos do processo, discussão fundamentada e conclusão clara. Em mais 
da metade dos laudos o perito foi acionado para responder os quesitos faltantes, prestar esclarecimentos ou realizar laudo complementar.

Não se conseguiu encontrar um critério uniforme utilizado pelos peritos para avaliar se o médico atuou ou não com negligência, imprudência ou imperícia, ou mesmo para a determinação do nexo causal. Os elementos da responsabilidade civil passíveis de apuração com maior grau de certeza foram os danos físicos, estéticos e materiais e os casos de evidente inobservância de regras técnicas.

Constataram-se três níveis de utilização do laudo nas sentenças: integral, parcial e irrelevante. Cerca de $80 \%$ das sentenças acolheram integralmente os respectivos laudos e $16 \%$ os acolheram parcialmente.

O papel da perícia é importante como meio de prova, porém esta pode apresentar falhas e/ou imperfeições, devendo o juiz estar sempre atento aos fatos do processo para, caso necessário, formar sua convicção com outros elementos demonstrados nos autos.

São Paulo, outubro de 2010.

\section{Referências}

ALCÂNTARA, Hermes Rodrigues de et al. Pericia médica judicial. 2. ed. Rio de Janeiro: Editora Guanabara Koogan, 2006.

ALMEIDA, Alessandra Juttel. É possível a cumulação entre dano moral e dano estético? Disponível em: <http://www.correioforense.com.br/anexos/danomoral/1139832093670.doc $>$. Acesso em: 20 nov. 2008.

BARROS, Felipe Luiz Machado. O dano estético e a responsabilização civil. Jus Navigandi, Teresina, ano 5, n. 49, fev. 2001. Disponível em: $<$ http://jus2.uol.com.br/doutrina/texto.asp?id=1870 $>$. Acesso em: 20 nov. 2008 .

BENJAMIN, Antonio Herman de Vasconcelos. Comentários ao Código do Consumidor. São Paulo: Editora Saraiva, 1991.

BITTAR, Eduardo C.B. Metodologia da pesquisa jurídica. 6. ed. São Paulo: Editora Saraiva, 2007. CINTRA, Antônio Carlos de Araújo; GRINOVER, Ada Pellegrini; DINAMARCO, Cândido Rangel. Teoria Geral do Processo. 19. ed. rev. e atual. São Paulo: Malheiros Editores, 2002. p. 348-352.

CONSELHO REGIONAL DE MEDICINA DO ESTADO DE SÃO PAULO. Denúncias e processos relacionados ao exercício profissional da medicina no Estado de São Paulo no período de 2000 a 2006. São Paulo, 9 out. 2007. Disponível em: <http://www.cremesp.org.br/library/modulos/centro_ de_dados/arquivos/denuncias_cremesp.pdf>. Acesso em: 20 nov. 2008. 
CONSELHO REGIONAL DE MEDICINA DO ESTADO DE SÃO PAULO. Especialidades médicas no Estado de São Paulo. São Paulo, 2008. Disponível em: <http://www.cremesp.org.br/ library/modulos/centro_de_dados/arquivos/especialidades.pdf $>$. Acesso em: 20 nov. 2008.

CONSELHO REGIONAL DE MEDICINA DO ESTADO DE SÃO PAULO. O trabalho do médico no Estado de São Paulo. São Paulo, 2007. Disponível em: <http://www.cremesp.org.br/library/ modulos/centro_de_dados/arquivos/mercado_de_trabalho.pdf $>$. Acesso em: 20 nov. 2008.

CONSELHO REGIONAL DE MEDICINA DO ESTADO DE SÃO PAULO. Perfil do médico. São Paulo, 2007. Disponível em: <http://www.cremesp.org.br/library/modulos/centro_de_dados/ arquivos/perfil_medico.pdf>. Acesso em: 20 nov. 2008.

COUTO FILHO, Antonio Ferreira; SOUZA, Alex Pereira. Responsabilidade civil médica e hospitalar. 2. ed. Rio de Janeiro: Editora Lumen Juris, 2008.

COUTO FILHO, Antonio Ferreira; SOUZA, Alex Pereira. A improcedência no suposto erro médico. 2. ed. rev., atual. e ampl. Rio de Janeiro: Editora Lumen Juris, 2002.

DINAMARCO, Cândido Rangel. Instituições de Direito Processual Civil. 4. ed. rev. e atual. São Paulo: Malheiros Editores, 2004.

DINIZ, Maria Helena. Curso de direito civil brasileiro: responsabilidade civil. 22. ed. São Paulo: Saraiva, 2008. v. 7.

FRANÇA, Genival Veloso de. A perícia do erro médico. Disponível em: <http://www.erromedico. org/genival_pericia.htm>. Acesso em: 20 nov. 2008.

FRANÇA, Genival Veloso de. Direito médico. 6. ed. São Paulo: Fundação BYK, 1994.

FRANÇA, Genival Veloso de. Medicina Legal. 8. ed. Rio de Janeiro, Editora Guanabara Koogan, 2008.

GONÇALVES, Carlos Roberto. Responsabilidade civil. 6. ed. São Paulo: Editora Saraiva, 1995.

KFOURI NETO, Miguel. Culpa médica e ônus da prova. São Paulo: Editora Revista dos Tribunais, 2002.

KFOURI NETO, Miguel. Responsabilidade civil do médico. 6. ed. São Paulo: Editora Revista dos Tribunais, 2007.

LOPES, João Batista. A prova no direito processual civil. 2. ed. rev., atual. e ampl. São Paulo: Editora Revista dos Tribunais, 2002.

LOPES, Tereza Ancona. O dano estético: responsabilidade civil. 3. ed. São Paulo: Editora Revista dos Tribunais, 2004.

MELO, Nehemias Domingos de. Responsabilidade civil por erro médico. 1. ed. São Paulo: Editora Atlas, 2008. 
MEZZAROBA, Orides; MONTEIRO, Cláudia Servilha. Manual de metodologia da pesquisa no Direito. 3. ed. São Paulo: Editora Saraiva, 2007.

MORAES, Irany Novah. Erro Médico e a Justiça. 5. ed. rev., atual. e ampl. São Paulo: Editora Revista dos Tribunais, 2003.

NEMETZ, Luiz Carlos; FRAGA, Flávio. O valor da prova pericial nas ações de erro médico. Boletim Jurídico, n. 155, dez. 2005. Disponível em: <http://www.boletimjuridico.com.br/doutrina/ texto.asp?id=958>. Acesso em: 25 jul. 2008.

RIBEIRO, Alex Sandro. Não se cumulam "danos estéticos" com danos morais e/ou materiais. Revista Âmbito Jurídico, Rio Grande, n. 15, nov. 2003. Disponível em <http://www.ambito-juridico. com.br/site/index.php?n_link=revista_artigos_leitura\&artigo_id $=4040>$. Acesso em: 20 nov. 2008.

ROCHA, Cleonice Rodrigues Casarin da. A responsabilidade civil decorrente do contrato de serviços médicos. Rio de Janeiro: Forense, 2005.

ROMANELLO NETO, Jerônimo. Responsabilidade civil dos médicos. São Paulo: Editora Jurídica Brasileira, 1998.

SALAMACHA, Consuelo Taques Ferreira. Erro médico: inversão do ônus da prova. 2. ed. Curitiba: Juruá, 2008.

SEBASTIÃO, Jurandir. Responsabilidade médica civil, criminal e ética: legislação positiva aplicável. Belo Horizonte: Del Rey, 1998.

SOUZA, Neri Tadeu Camara. Responsabilidade civil no erro médico. Disponível em: <http://www. saude.sc.gov.br/gestores/sala_de_leitura/artigos/outros/erro.pdf $>$. Acesso em: 20 nov. 2008.

STOCO, Rui. Tratado de responsabilidade civil. 6. ed. rev., atual. e ampl. São Paulo: Editora Revista dos Tribunais, 2004.

THEODORO JÚNIOR, Humberto. Aspectos processuais da ação de responsabilidade por erro médico. Revista de Processo, n. 95.05 dez. 2005. São Paulo: Editora Revista dos Tribunais, 1999.

UDELSMANN, Artur. Responsabilidade civil, penal e ética dos médicos. Revista da Associação Médica Brasileira, v. 48, n. 2, abr./jun. 2002. Disponível em: <http://www.scielo.br/scielo. php?script=sci_arttext\&pid=S0104-42302002000200039>. Acesso em: 20 nov. 2008.

WAMBIER, Luiz Rodrigues (Coord.); ALMEIDA, Flávio Renato Correia de; TALAMINI, Eduardo. Curso avançado de processo civil: teoria geral do processo e processo de conhecimento. 8. ed. rev., atual. e ampl. São Paulo: Editora Revista dos Tribunais, 2006. v. 1. 